Psychological Monographs, 1962, 76(39), Whole No. 558.

HEADRICK, M. W., \& GRAHAM, F. K. Multiple component heart rate responses conditioned under paced respiration. Journal of Experimental Psychology, 1969, 79, 486-494.

LOCKHART, R. A. Comments regarding multiple response phenomena in long interstimulus interval conditioning. Psychophysiology, 1966a, 3, 108-114.

LOCKHART, R. A. Recent developments in the classical conditioning of autonomic responses. Symposium on Higher Nervous Activity, Fourth World Congress of Psychiatry, Madrid, Spain, 1966b.

LOCKHART, R. A. Distinguishing component processes reflected in autonomic behavior of human subjects during classical conditioning. International Journal of Psychobiology, 1970, in press.

LOCKHART, R. A., \& GRINGS, W. W. Interstimulus interval effects on GSR discrimination conditioning. Journal of Experimental Psychology, 1964, 67, 209-214. STERN, J. A., STEWART, M. A., \& WINOKUR, G. An investigation of some relationships between various measures of galvanic skin response. Joumal of Psychosomatic Research, 1961, 5, 215-223.

STEWART, M. A., STERN, J. A., WINOKUR, G., \& FREDMAN, S. An analysis of GSR conditioning. Psychological Review, 1961, 68, 60-67.

\section{NOTES}

1. This investigation was supported by a grant from USPHS (MH 12879-02). We wish to thank Larry Walrath, Mary Kidd, and Martha Cummings for their helpful assistance.

2. This point should not be overly stressed since differential responding in the 10-sec condition approached significance during Day 2 (see Fig. 1). During Day 2 (particularly in the late trials), responding to $\mathrm{CS}-$ changed from deceleration to a slight acceleration.

\title{
Agonistic behavior in mice: Strain differences as a function of test illumination ${ }^{1}$
}

\section{T. W. KLEIN, J. HOWARD, and J. C. DeFRIES, University of Colorado, Boulder, Colo. 80302}

In each of two experiments, C57BL (pigmented) mice were paired with members of the $B A L B / c$ (albino) strain under either high or low illumination and their agonistic behovior observed. In both experiments, under high illumination, C57BL Ss won approximately $90 \%$ of the bouts that resulted in submission. In contrast, under low illumination, C57BL mice won about $40 \%$ of the bouts, resulting in highly significant interactions between strain and level of test illumination. These results may explain the apparent inconsistency in the literature concerning the agonistic behavior of these two inbred strains.

McClearn (1967) has recently discussed the utility of inbred strain comparisons in behavioral research: For each of several strains, independent investigations have provided a profile for a variety of behaviors that are stable over time and space. These strain profiles are cumulative and permit characterization of members of a given strain for a number of traits. However, differential responses of different genotypes to changes in environmental conditions have also been reported. For example, differential effects of test illumination on the open-field behavior of albino and pigmented mice are well documented (McClearn, 1960; DeFries,
Hegmann, \& Weir, 1966; McReynolds, Weir, \& DeFries, 1967). When apparent inconsistencies in strain profiles are found, the possibility of a genotype-environment interaction should be considered.

Inbred strains have been widely used in studies of aggressive behavior in mice (Lagerspetz, 1964). Characteristically, one male from each of two inbred strains is placed in a neutral cage and agonistic behavior is observed. Using this procedure, Ginsburg \& Allee (1942) studied the effects of conditioning on social dominance in inbred strains of mice. In their initial experiments, they found that members of the C57BL strain were more aggressive than those of the $\mathrm{C} 3 \mathrm{H}$ strain, both of which were more aggressive than the $\mathrm{C}$ albino strain (BALB/c). In these experiments, a relatively high level of illumination was employed (a 60-W lamp placed $19 \mathrm{in}$. above the floor of the test cage). In a recent review of social behavior in the laboratory mouse, Wimer \& Fuller (1966) indicate that several researchers have subsequently used $B A L B / c$ mice as relatively nonaggressive Ss.

In contrast to the findings of Ginsburg \& Allee (1942), Scott (1942) has described the C57BL/10 strain as being "pacifist." Similarly, Tellegen, Horn, \& Legrand (1969) reported that C57BL/6J mice rarely fight vigorously when attacked; thus, they were suitable "standard victims" in an experiment to test the reinforcing properties of opportunity for aggression by BALB/cJ mice. Casual observation of Ss in experiments concerning social dominance in our laboratory suggest that $\mathrm{BALB} / \mathrm{c}$ (albino) mice are more aggressive than C57BL (pigmented) mice under relatively low levels of illumination. The primary objective of the present study was to test the hypothesis that level of test illumination will differentially influence the agonistic behavior of $B A L B / c$ and C57BL mice, which may account for the apparent inconsistency in the literature regarding the social dominance of these two inbred strains.

\section{METHOD}

In an initial experiment, six males from each of two inbred strains (BALB/cIbg and C57BL/lbg) were tested under each of two levels of illumination. The high-illumination condition was similar to that employed by Ginsburg \& Allee (a $60-\mathrm{W}$ incandescent bulb suspended 19 in. above the floor of the test cage), whereas low illumination was provided by a dim red light. Ss in this experiment were not experimentally naive; however, mice were individually housed in separate cages for at least 3 weeks prior to the beginning of the experiment. Each S (approximately 100 days of age) participated in one bout on each of six successive evenings. A bout consisted of placing two male mice in a stainless steel cage $(12 \times 8 \times 4$ in. $)$ separated by a partition for a period of $5 \mathrm{~min}$. The partition was then raised and the Ss were observed for $20 \mathrm{~min}$ through a clear Plexiglas cover. Bouts were terminated prior to $20 \mathrm{~min}$ if the fight was severe enough to produce bleeding. Within illumination condition, each BALB mouse was successively paired with every C57BL mouse, resulting in a total of 36 bouts for each condition.

In a subsequent experiment, several alterations in procedure were adopted: Experimentally naive $S s$ (individually housed for at least 75 days) were administered fighting experience in an attempt to increase the frequency of aggressive behavior. Each $\mathrm{S}$ (ranging in age from 99 to 125 days) was randomly paired for 20 bouts over a 4 -week period prior to final testing. In this experiment, the high-illumination condition was the same as that described above. However, low illumination was provided by raising the $60-\mathrm{W}$ bulb to approximately $8 \mathrm{ft}$ above the floor of the test cage. This resulted in levels of illumination of about 45- and 3-fc incident light for the high and low conditions, respectively. Training experience and final testing were conducted under the same levels of illumination.

The classical submissive posture (rearing back on hind legs with one foreleg drawn close to the body and the other stiffly 
Table 1

Number of Wins for Each of Two Inbred Strains of Mice Under High- and Low-Illumination Conditions

\begin{tabular}{lrrrrr}
\hline & \multicolumn{2}{c}{ Experiment 1 } & & \multicolumn{2}{c}{ Experiment 2 } \\
\cline { 2 - 5 } Strain & \multicolumn{2}{c}{ Illumination } & & \multicolumn{2}{c}{ Illumination } \\
BALB & Low* & & \multicolumn{2}{c}{ High } & Low $^{*}$ \\
C57BL & 3 & 14 & 3 & 13 \\
\hline
\end{tabular}

* Low illumination in the initial experiment was produced by a dim red light.

outstretched) was used as the criterion for a loss. Data recorded included strain of $S$ making initial attack (biting), strain of winner, and whether each $S$ was active or passive. An $S$ was considered active if it sought out its opponent and passive if contact was of a casual nature.

RESULTS AND DISCUSSION

The number of wins observed for members of each strain under the two levels of illumination in each experiment are presented in Table 1. The overwhelming success of members of the C57BL strain under high illumination may be seen from the results of both experiments and is in close agreement with the results of Ginsburg \& Allee (1942). In contrast, under conditions of low (either red or white) illumination, C57BL mice exhibit lower levels of agonistic behavior, resulting in highly significant interactions between strain and level of illumination $\left(\chi^{2}=14.44\right.$ and $\left.14.85, p<.001\right)$. The similarity between the results of the initial and subsequent experiments is particularly striking in view of the differences in test procedure employed. Unfortunately, however, these differences preclude a direct test of the effectiveness of pretest experience in increasing aggressiveness.

The availability of more complete data from Experiment 2 made additional analyses possible. A correlation between performance on successive encounters has been discussed by Ginsburg \& Allee (1942). In order to check whether the significant interaction between strain and level of illumination observed above was an artifact of the repeated pairing of Ss within each group, the data of Day 1 were examined separately. During the six bouts under high illumination on Day 1 , four were won by members of the C57BL strain, whereas none were won by BALB mice. Under low illumination, however, BALB mice won five bouts, while C57BL Ss won none. A chi-square test (corrected for continuity) was applied to these data $\left(\chi^{2}=5.40, \mathrm{p}<.025\right)$ and confirmed the significant interaction between strain and level of illumination.

$R$ andom assignment of $S s$ to illumination level resulted in an inequality with regard to mean body weight. When Ss were weighed on the initial day of testing, BALB mice tested under high and low levels of illumination weighed $25.7 \mathrm{~g}$ and $28.4 \mathrm{~g}$, respectively, and C57BL Ss weighed $26.0 \mathrm{~g}$ and $25.2 \mathrm{~g}$, respectively. In view of the possible relationship between weight and agonistic behavior, the results observed above might have been due to initial weight differences. Thus, initial weight data and number of wins for each $S$ over the six bouts were subjected to an analysis of covariance. When number of wins per $S$ was corrected for initial weight by this procedure, significant effects due to strain $(\mathrm{F}=9.62, \mathrm{df}=1 / 19, \mathrm{p}<.01)$ and Strain by Illumination interaction $(F=20.91$, $\mathrm{df}=1 / 19, \mathrm{p}<.005$ ) were found. This result indicates that initial weight differences did not account for the highly significant interaction between strain and level of illumination for total number of wins.

For each strain and level of illumination, the number of active (nonpassive) $S s$ and the number of initial attacks are shown in Table 2. For both characters, a significant interaction between strain and level of illumination was observed $\left(\chi^{2}=3.92\right.$, $\mathrm{p}<.05 ; \chi^{2}=9.82, \mathrm{p}<.005$, respectively). In each case, the interaction was in the direction of that for total number of wins and suggests that an $S$ that actively seeks out or initially attacks its opponent has a higher probability of eventually winning the bout. However, wins may occur without an initial attack, as, for example, when sniffing by one $S$ results in a submissive posture by its opponent.

In the present study, the agonistic behavior of albino and pigmented strains of mice was differentially influenced by changes in level of illumination. Less extreme, although marked, interactions between level of illumination and genotype
Table 2

Number of Active (Nonpassive) Animals and Number of Initial Attacks for Each of Two Strains of Mice Under High and Low Levels of Illumination

\begin{tabular}{|c|c|c|c|}
\hline \multirow{3}{*}{\multicolumn{2}{|c|}{ Strain $\begin{array}{c}\text { Number } \\
\text { of Active } \\
\text { (Nonpassive) Ss } \\
\begin{array}{l}\text { Illumination } \\
\text { High Low }\end{array}\end{array}$}} & \multirow{2}{*}{\multicolumn{2}{|c|}{$\begin{array}{c}\begin{array}{c}\text { Number } \\
\text { of Initial } \\
\text { Attacks }\end{array} \\
\text { Illumination }\end{array}$}} \\
\hline & & & \\
\hline & & High & Low \\
\hline $\mathrm{BALB} / \mathrm{c}$ & 26 & 7 & 16 \\
\hline C57BL & 22 & 15 & 4 \\
\hline
\end{tabular}

have been observed for other behaviors (cf. McClearn, 1960; DeFries, Hegmann, \& Weir, 1966; McReynolds, Weir, \& DeFries, 1967). Thus, when genotype-environment interactions occur (as may be expected, for example, when albino and pigmented Ss are compared under varying levels of illumination), strain profiles require an additional dimension in order to achieve generality.

\section{REFERENCES}

DeFRIES, J. C., HEGMANN, J. P., \& WEIR, M. W. Open-field behavior in mice: Evidence for a major gene effect mediated by the visual system. Science, 1966, 154, 1577-1579.

GINSBURG, B., \& ALLEE, W. C. Some effects of conditioning on social dominance and subordination in inbred strains of mice. Physiological Zoology, 1942, 15, 485-506.

LAGERSPETZ, K. Studies on the aggressive behaviour of mice. Helsinki: Suomalainen Tiedeakatemia, 1964.

MOCLEARN, G. E. Strain differences in activity of mice: Influence of illumination. Journal of Comparative \& Physiological Psychology, $1960,53,142-143$

MCCLEARN, G. E. Genes, generality and behavior research. In J. Hirsch (Ed.), Behavior-genetic analysis. New York: McGraw-Hill, 1967. Pp. 307-321.

MCREYNOLDS, W. E., WEIR, M. W., \& DeFRIES, J. C. Open-field behavior in mice: Effect of test illumination. Psychonomic Science, 1967, 9, 277-278.

SCOTT, J. P. Genetic differences in the social behavior of inbred strains of mice. Journal of Heredity, 1942, 33, 11-15.

TELLEGEN, A., HORN, J. M., \& LEGRAND, R. G. Opportunity for aggression as a reinforcer in mice. Psychonomic Science, 1969, 14, 104-105.

\section{NOTE}

1. Supported in part by NIH Grant GM-14547. We thank Mr. Larrie G. Pickett for collecting the data of the initial experiment. 